\title{
Pendugaan Produksi Dan Indeks Vegetasi Tanaman Padi Menggunakan Data Citra Platform Unmanned Aerial Vehicle (UAV) Dan Data Citra Satelit Landsat 8
}

\author{
Winda Vitasari ${ }^{1}$, Daniel ${ }^{1}$ dan Ahmad Munir ${ }^{1}$ \\ Program Studi Teknik Pertanian, Universitas Hasanuddin Makassar
}

\begin{abstract}
ABSTRAK
Beras berasal dari padi atau gabah yang dibudidayakan sehingga menjadi bahan pokok makanan seperti sekarang ini. Padi (Oryza sativa L) merupakan aspek paling utama pada pertanian. Produksi padi dapat diketahui setelah masa panen berakhir. Maka itu dibutuhkan suatu informasi untuk mengetahui hasil produksi sebelum masa panen. Pemanfaatan GIS (Geograpichal Information System) atau dikenal sebagai Sistem Informasi Geografis (SIG) dapat membantu mengelola sumber daya pertanian. Pemanfaatan penginderaan jauh berupa citra fotografik UAV (Unmanned Arial Vehicle) dan citra satelit Landsat 8, kita dapat memantau pertumbuhan tanaman padi serta memperoleh informasi tingkat produksi lahan sawah. Tujuan dari penelitian ini untuk memprediksi tingkat produksi tanaman padi dari hasil citra dan melihat keakuratan klasifikasi terpantau terhadap citra fotografik UAV. Metode yang digunakan pada penelitian ini adalah Klasifikasi terpantau pada software, dengan menggunakan data lapangan. Hasil klasifikasi terpantau menunjukkan persentase untuk produksi rendah $22 \%$, produksi sedang $51 \%$ dan produksi tinggi $27 \%$. Tingkat kesalahan tertinggi pada klasifikasi tingkat produksi tinggi sebanyak 47,05\%. Berdasarkan penelitian yang telah dilakukan dapat disimpulkan bahwa overall accuracy adalah $73,01 \%$. Hal ini berarti tingkat ketelitian akurasi dapat diterima. Indeks vegetasi yang terbaik dalam pendugaan produksi pada tingkat varietas adalah varietas VARIgreen.
\end{abstract}

Kata Kunci: Padi (Oryza sativa L), citra UAV, Citra Satelit Landsat 8, Indeks Vegetasi.

\section{PENDAHULUAN}

\section{Latar Belakang}

Beras berasal dari padi atau gabah yang dibudidayakan sehingga menjadi makanan pokok seperti sekarang ini. Padi (Oryza sativa L) merupakan tanaman pangan yang sangat penting di Indonesia, menurut laporan dari FAO (Food and Agriculture Organization) Indonesia menduduki peringkat ke tiga dalam penghasil beras terbesar di dunia, dengan jumlah produksi 70,8 juta ton pertahunnya. Diperkirakan padi menyumbangkan 60-80 $\%$ kalori dan 45-55 \% protein dalam umur rata-rata masyarakat Indonesia.

Kabupaten Maros merupakan salah satu daerah pertanian dan salah satu daerah lumbung pangan di Sulawesi Selatan. Berdasarkan data BPS (Badan Pusat Statistik) Kab. Maros tahun 2010, luas lahan panen dan produksi padi masingmasing 44.097 ha dan 262.641,73 ton dengan produksi 5,95 t/ha. Banyak upaya yang dilakukan oleh pemerintah Maros dalam mengembangkan produksi padi untuk mewujudkan Indonesia menjadi negara penghasil padi terbesar di dunia.

Pemanfaatan GIS (Geographical Information System) adalah salah satu sistem basis data dengan kemampuan khusus untuk menangani data yang bereferensi keruangan (spasial) bersamaan dengan seperangkat operasi kerja. GIS dapat membantu mengumpulkan data secara cepat. GIS dapat digunakan untuk membantu mengelola sumber daya pertanian dan perkebunan seperti luas kawasan untuk tanaman atau saluran air. Data citra Platfrom Unmanned Aerial Vehicle (UAV) merupakan salah satu contoh pemanfaatan GIS. Dengan pesawat tanpa awak yang dapat menyimpan dan 
mengambil gambar dari ketinggian tertentu. Tingkat produksi tanaman yang dilihat pada citra disesuaikan pada area lahan baik itu keseluruhan maupun pada perhitungan luasan per petak sawah. Dari hasil pemantauan itu sendiri nantinya tingkat produksi dapat dipetakan. Pemetaan tingkat produksi dilakukan dengan mengklasifikasikan tiap tingkat berdasarkan data lapangan. Sehingga dapat dilihat bagaimana keakuratan dan ketepatan penginderaan jauh.

Indeks vegetasi atau besaran nilai kehijauan vegetasi yang diperoleh dari pengolahan sinyal digital beberapa kanal data sensor satelit, dapat memberikan informasi bahwa suatu tanaman bervegetasi baik. Indeks vegetasi yang baik salah satu faktor yang mempengaruhi kondisi suatu tanaman padi sehat dan mempengaruhi produksi yang dihasilkan.

Maka dari itu dilakukan penelitian ini untuk dapat memetakan tingkat poduksi suatu lahan sawah berdasarkan klasifikasi data hasil panen di lapangan melalui citra fotografik UAV dan melihat indeks vegetasi dari tanaman padi berdasarkan data citra satelit landsat 8 .

\section{Tujuan dan Kegunaan}

Tujuan dari penelitian ini adalah untuk memetakan tingkat produksi tanaman mengunakan citra UAV dan data citra satelit Landsat 8 dengan pendekatan indeks vegetasi.

Kegunaan penelitian ini yaitu memberikan informasi berupa layout peta mengenai tingkat produksi lahan sawah secara spesifik.

\section{TINJAUAN PUSTAKA}

\section{Tanaman Padi}

Tanaman padi adalah jenis tumbuhan yang sangat mudah ditemukan apalagi yang tinggal di daerah pedesaan. Hamparan persawahan dipenuhi dengan tanaman padi. Sebagian besar menjadi padi sebagai sumber bahan makanan pokok. Padi merupakan tanaman yang termasuk debus Oezya L. yang meliputi kurang lebih 25 spesies, tersebar di daerah tropis dan daerah subtropis, seperti Asia, Afrika, Amerika dan Australia. Padi yang ada sekarang merupakan persilangan antara Oryza officianalis dan Oryza sativa $F$. Spontane. Tanaman padi termasuk tanaman yang berumur pendek. Biasanya hanya berumur kurang dari satu tahun dan berproduksi satu kali. Setelah tanaman padi ini berbuah dan dipanen, padi tidak tumbuh seperti semula lagi (Irfan, 2013).

\section{Varietas padi}

Varietas merupakan suatu peringkat taksonomi sekunder di bawah spesies. Suatu varietas menunjukan penampilan yang khas dan berbeda dari varietas lain, tetapi akan bersilang dengan bebas terhadap varietas lain (jika dilakukan kontak dengannya). Berikut merupakan beberapa deskripsi varietas tanaman padi:

1. Inpari 4

2. Inpari 23

3. Ciliwung

\section{Produktivitas Lahan Sawah}

Secara fisik, lahan sawah merupakan suatu ekosistem lahan yang relatif stabil dan mempunyai keberkelanjutan sangat tinggi. Hal ini dicirikan dengan penyediaan dan peredaran hara yang lebih efisien, rendahnya perkolasi, erosi dan pencucian hara karena adanya lapisan tapak bajak (plow pan), terjadinya penambahan hara secara alami dari air irigasi, dan lain-lain. Namun karena pengelolaan lahan yang kurang tepat lahan sawah sering mengalami penurunan kesuburan atau produktivitas dan sering disebut dengan tanah sakit. Selain itu lahan sawah juga sering mengalami degradari akibat pencemaran, baik yang disebabkan limbah agrokimia, industri, dan domestik (perubahan /perkotaan) (Bagio, 2011).

Produktivitas lahan sawah dapat menurun sebagai akibat dari : (1) pengurasan dan deficit hara karena yang 
terbawa lebih banyak dari hara yang diberikan melalui pemupukan atau penambahan dari air irigasi; (2) kelebihan pemberian hara tertentu dan kekurangan hara lainnya karena pemupukan yang tidak berimbang, dan (3) penurunan kadar bahan organik tanah. Degradasi tersebut tidak saja mengancam kuantitas (produktivitas) hasil padi, tetapi juga kualitasnya (Wahyunto, 2006).

\section{Sistem Informasi Geografis (SIG)}

Sistem informasi geografis (SIG) atau Geographic Information System (GIS) adalah sebuah sistem yang didesain untuk menyimpan, memanipulasi, menganalisa, mengatur dan menampilkan seluruh jenis data geografis. Akronim GIS terkadang dipakai sebagai istilah untuk geographical information science atau geospatial information studies yang merupakan ilmu studi atau pekerjaan yang berhubungan dengan Geographic Information System. Dalam artian sederhana sistem informasi geografis dapat kita simpulkan sebagai gabungan kartografi, analisis statistik dan teknologi sistem basis data (database). SIG tidak lepas dari data spasial, yang merupakan sebuah data yang mengacu pada posisi, objek dan hubungan diantaranya dalam ruang bumi. Data spasial merupakan salah satu item dari informasi di mana di dalamnya terdapat informasi mengenai bumi termasuk permukaan bumi, di bawah permukaan bumi, perairan, kelautan dan bawah atmosfer.

\section{Citra Satelit UAV (Unmanned Aerial Vchiclel)}

UAV merupakan sistem tanpa awak (Unmanned System), yaitu sistem berbasis elektro-mekanik yang dapat melakukan misi-misi terprogram, dengan karakteristik yaitu tanpa awak pesawat, beroperasi pada mode mandiri baik secara penuh atau sebagian, dan sistem ini dirancang untuk dapat dipengaruhi secara berulang. Teknologi pemetaan tanpa awak menjadi pilihan alternatif disamping teknologi pemetaan pemetaan lainnya seperti pemotretan udara baik skala besar dan kecil berawak serta pemetaan berbasis satelit. Teknologi ini sangat menjanjikan untuk diaplikasikan dikembangkan dan sesuai karakteristik topografi dan geografis Indonesia. UAV biasanya dilengkapi dengan alat atau sistem pengendali terbang melalui gelombang radio, navigasi presisi (Grounding Positioning System - GPS dan pengukuran Internal Unit), dan elektronik kontrol penerbangan, dan peralatan kamera resolusi tinggi (Shofiyanti, 2011).

\section{Indeks Vegetasi Tanaman}

Menurut Cambell (2011), Indeks vegetasi atau vegetation index dianalisa berdasarkan nilai-nilai kecerahan digital, dilakukan untuk percobaan mengukur biomassa atau vegetatif. Sebuah indeks vegetasi terbentuk dari kombinasi dari beberapa nilai spektral dengan menambahkan, dibagi atau dikalikan dengan cara yang dirancang untuk menghasilkan nilai tunggal yang menunjukkan jumlah atau kekuatan vegetasi dalam pixel.

Indeks vegetasi adalah besaran nilai kehijauan vegetasi yang diperoleh dari pengolahan sinyal digital data nilai kecerahan (brightness) beberapa kanal data sensor satelit. Untuk pemantauan vegetasi, dilakukan proses pembandingan antara tingat kecerahan kanal cahaya (Red) dan kanal inframerah dekat (near infrared). Gelombang vegetasi diperoleh dari energi yang dipancarkan oleh vegetasi pada citra penginderaan jauh untuk menunjukkan ukuran kehidupan dan jumlah dari suatu tanaman. Nilai indeks vegetasi yang tinggi memberikan gambaran bahwa di area yang diamati terdapat vegetasi yang mempunyai tingkat kehijauan tinggi. Sebaliknya nilai indeks vegetasi yang rendah merupakan indikator bahwa lahan yang menjadi objek pemantauan mempunyai tingkat kehijauan rendah atau lahan dengan vegetasi sangat jarang. 
Jenis Indeks Vegetasi

1. Normalized Difference Vegetation Index (NDVI)

NDVI adalah indeks yang menggambarkan tingkat kehijauan suatu tanaman. NDVI merupakan kombinasi matematis antara band merah dan band NIR yang telah lama digunakan sebagai indikator keberadaan dan kondisi vegetasi. NDVI dapat digunakan sebagai indikator biomassa dan tingkat kehijauan (greeness) relatif (Faizal, 2005).

$N D V I=\frac{(N I R-R e d)}{(N I R+R e d)}$

Keterangan :

NIR : Radiasi infra merah dekat dari piksel

Red : Radiasi cahaya merah dari piksel Nilai

2. Green Normalized Difference Vegetation Index (GNDVI)

Indeks vegetasi yang menormaslisasikan indeks kehijauan, indeks ini mirip dengan NDVI, hanya saja pada indeks vegetasi ini mengukur spektrum hijau 540-570 nm bukan spektrum merah. Indeks ini lebih sensitif terhadap konsentrasi klorofil dari NDVI (Faizal, 2005).

GNDVI $=\frac{(\text { NIR-Green })}{(\text { NIR }+ \text { Green })}$

Keterangan :

NIR : Radiasi infra merah dekat dari piksel

Green : Radiasi cahaya hijau dari piksel

3. Visible Atmospherically Resistant Index (VARIgreen)

Indeks ini adalah indeks perangkat tambahan untu NDVI yang relatif tahan terhadap faktor atmosfer. Indeks ini digunakan untuk memperbaiki tingkat vegetasi kehijauan dalam sebuah tanaman (Faizal, 2005).
VARIgreen $=\frac{(\text { Green }- \text { Red })}{(\text { Green }+ \text { Red }- \text { Blue })}$...........

Keterangan :

Red : Radiasi cahaya merah dari piksel

Green : Radiasi cahaya hijau dari piksel

Blue : Radiasi cahaya biru dari piksel

\section{Pengolahan Data Citra}

Ada tiga bidang studi utama yang menangani pengolahan data berbentuk gambar atau citra yaitu, computer, pengolah citra, dan pengenalan pola. Karena pengenalan pola sering merupakan juga bagian dari pengolahan citra seperti misalnya pada proses klasifikasi maka pembedaan tiga bidang dari pengolahan citra seperti misalnya pada proses klasifikasi maka pembedaan tiga bidang sttudi tersebut berubah menjadi : grafik computer, pengolahan citra, dan visi computer, dimana pengenalan pola menjadi bagian dari pengolahan citra dan juga bagian dari visi computer (Santi, 2011).

Pengolahan citra merupakan proses pengolahan dan analisi citra yang banyak melibatkan persepsi visual. Proses ini mempunyai ciri data masukan dan informasi keluaran yang berbentuk citra. Dalam kenyataannya, batas antara ketiga bidang studi di atas sulit untuk ditentukan. Sebagai contoh, dalam proses pembuatan film animasi, objek dan proses animasinya diciptakan dengan teknik grafik computer sedangkan pembuatan latar belakangnya dapat dilakukan dengan teknik pengolahan data citra. Di sini latar belakang gambar dapat dibuat secara sederhana melalui kombinasi proses digitasi suatu foto dan proses pembesaran atau penggulungan atau dapat pula dengan teknik lebih rumit (Santi, 2011).

Pixel adalah sebuah titik yang merupakan elem paling kecil pada citra satelit, angka numerik ( 1 byet) dari Pixel disebut nilai digital (DN). DN bias ditampilkan dalam warna kelabu, berkisar antara putih dan hitam (gry scale), tergantung level energi yang terdeteksi. 
Pixel yang disusun dalam order yang benar akan membentuk sebuah citra. Kebanyakan citra satelit yang belum diproses disimpan dalam bentuk gray scale, yang merupakan skala warna dari hitam ke putih dengan derajat keabuan yang bervariasi. Untuk penginderaan jauh, skala yang dipakai adalah 256 shade gray scale, dimana nilai 0 menggambarkan hitam, nilai 255 putih (Cifor, 2014).

\section{METODOLOGI PENELITIAN}

\section{Waktu dan Tempat}

Penelitian Pendugaan Produksi Tanaman Padi Menggunakan Indeks Vegetasi Melalui Citra Platform Unmanned Aerial Vehicle (UAV) Dan Data Citra Satelit Landsat 8, dilaksanakan mulai bulan Mei sampai Agustus 2016, mengikuti periode satelit Landsat-8 lewat di Wilayah Desa Aletengngae, Kecamatan Bantimurung. Kabupaten Maros.

\section{Alat dan Bahan}

Alat yang digunakan pada penelitian ini adalah laptop, software Er Mapper 7.1, software Argis 10.1, software Global Mapper 12, Citra Fotografik Vertikal UAV dan DRONE Model DJI Phantom 2+.

Bahan yang digunakan adalah Citra Satelit Landsat-8 TM Kabupaten Maros, peta dasar lahan petakan sawah dan peta hasil panen petakan sawah Kecematan Bantimurung.

\section{Prosedur Penelitian}

\section{a. Prosedur Pengambilan Data Lapangan}

1. Pengambilan Citra

Perekaman danengambilan data citra menggunakan DRONE Modul DJI Phantom 2+ dengan ketinggian tertentu. Dimana perekaman tersebut meliputi area persawahan. Selain itu pengambilan data dilakukan dengan rentan waktu setiap dua minggu untuk satu kali pengambilan, mengikuti periode satelit Landsat 8 lewat di wilayah tersebut.

2. Pengukuran Hasil Tanaman

Pengukuran hasil tanaman dilakukan selama masa panen berlangsung. Pengukuran hasil panen ini dilakukan berdasarkan dari masing-masing petakan sawah kemudian mengukur berat massa dan hasil panen tersebut.

\section{b. Rektifikasi Citra}

Rektifikasi citra lebih sering dilakukan untuk citra analog yang berupa foto. Hal ini digunakan untuk menyamakan dan memperjelas titik koordinat yang dimana sering terjadi pergeseran. Rektifikasi citra ini dilakukan pada software Global Mapper.

\section{c. Training Area}

Training Area dilakukan dengan mengambil beberapa petak sawah yang telah diketahui hasilnya dari data lapangan yang selanjutnya digunakan untuk memisahkan tingkatan suatu lahan sawah, sesuai dengan keseragaman atau kemiringan antara nilai piksel citra lokasi sampel dengan lokasi yang lain.

\section{d. Klasifikasi Terpantau}

Klasifikasi yang digunakan yaitu klasifikasi terpantau (supervised classification) dengan metode maximumlikehoodstandard (peluang maksimum) yang dilakukan pada software Arcgis 10.1 pada saat akan mengklasifikasi data yang digunakan didasarkan pada data hasil panen di lapangan yang memiliki suatu kelas yang akan diklasifikasikan. Berdasarkan hal itu tingkat produksi lahan sawah diklasifikasikan ke dalam tiga kelas, dan citra yang telah di training kemudian diklasifikasikan berdasarkan kelas-kelas yang telah disediakan oleh peneliti. Kelas-kelas tersebut adalah (Gunawan, 2012) : 
1. Produksi Rendah: $2-5$ ton/ha

2. Produksi Sedang: $>5-8$ ton/ha

3. Produksi Tinggi: $>8-10$ ton/ha

\section{e. Validasi Data dan Analisis Akurasi Citra Fotografik}

Validasi data digunakan untuk mengetahui tingkat ketelitian citra fotografik dalam mengklasifikasikan sesuai dengan data lapangan. Validasi dilakukan dengan mengecek lokasi yang di identifikasi citra sesuai tingkat produksi. Mencatat jumlah lokasi yang di klasifikasi dengan keadaan sebenarnya. Membuat confusion matrix dan mencatat nilai-nilai kedalam tabel.Analisis akurasi citra untuk mengetahui ketelitian hasil klasifikasi dengan data lapangan. Persamaan yang digunakan dalam menghitung akurasi sebagai berikut (Ekadiandita, 2008):

a. Prosedur menghitung User Accuracy

$$
\frac{z}{n_{\text {fakta }}} \times 100 \%
$$

Keterangan:

$\mathrm{n}_{\text {fakta }}:$ jumlah koordinat validasi

$\mathrm{Z} \quad$ : jumlah koordinat yang terbukti pada validasi

b. Prosedur menghitung prosedur

Accurarasy

$\frac{z}{n_{\text {citra }}} \times 100 \%=\pi r^{2}$

Keterangan:

$\mathrm{n} \quad$ : Koefisien Persen matriks (\%)

z : Jumlah koordinat yang terbukti pada validasi

c. Prosedur menghitung Metode

Matriks:

$K_{\text {hat }} \frac{N \sum_{i=1}^{r} x i i-\sum_{i=1}^{r}\left(x_{i+} * x_{+1}\right)}{N^{2}-\sum_{i=1}^{r}\left(x_{i+*} x_{+i}\right)}$.

Keterangan:

$\mathrm{K}_{\text {hat }}$ : Koefisien Persen Matriks $(\%)$

$\mathrm{N}$ : Jumlah Sampel Matriks

$\sum_{i=1}^{r}\left(x_{i+} * x_{+i}\right)$ :Perkalian dari Penjumlahan antar baris kolom matriks d. Prosedur menghitung Overal Accuracy

$\frac{x}{N} x 100 \%=\pi r^{2}$

Keterangan:

$\mathrm{N}$ : Jumlah Sampel Matriks

$X \quad$ : Jumlah diagonal matriks

\section{Persamaan Indeks Vegetasi}

1. Untuk menghitung indeks vegetasi Normalized Difference Vegetation Index (NDVI), dapat dilihat pada persamaan 1.

2. Untuk menghitung indeks vegetasi Green Normalized Difference Vegetation Index (GNDVI), dapat dilihat pada persamaan 2 .

3. Untuk menghitung indeks vegetasi Visible Atmospherically Resistant Index (VARIgreen), dapat dilihat pada persamaan 3 .

\section{Output}

Adapun output dari hasil penelitian ini adalah peta dasar hasil klasifikasi lahan sawah yang terdapat di desa Alatengngae, kecamatan Bantimurung, kabupaten Maros. 
Bagan Alir Penelitian

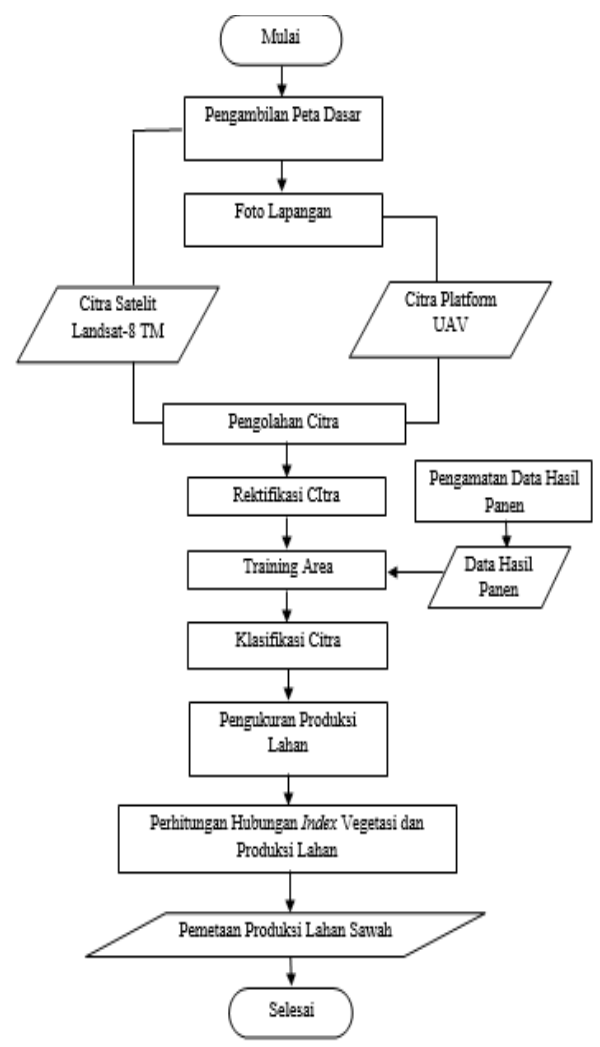

\section{HASIL DAN PEMBAHASAN}

\section{Klasifikasi Hasil Pengukuran Lapangan}

\section{Hasil Data Produksi Lahan Sawah}

Pada peta memperlihatkan 152 petak (Gambar 5) memiliki luasan yang berdeda-beda. Pada lokasi ini digunakan 63 petak sebagai titik pengamatan data. Hasil data produksi lahan sawah di bawah merupakan data lapangan yang diperoleh dari hasil produksi atau panen pada bulan Agustus 2016.

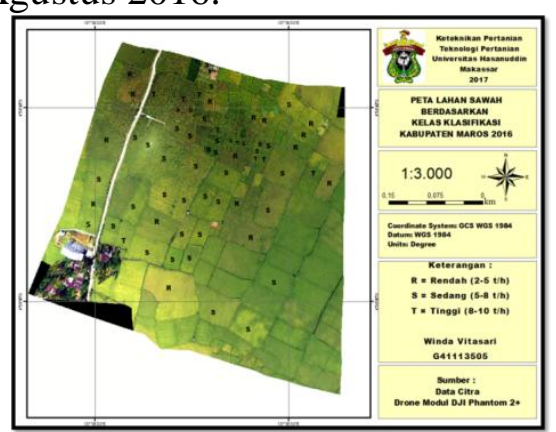

Gambar 5. Peta Lahan Sawah dengan

Tingkat Produksi Petak
Sebelum memasuki tahap klasifikasi menggunakan software pengolahan data citra, data hasil pengukuran produksi panen di masukkan kedalam kelas-kelas yang telah disedikan oleh peneliti. Kelas tersebut dibagi menjadi tiga kelas yaitu kelas produksi rendah yaitu 2-5 ton/ha, untuk kelas produksi sedang yaitu $>5-8$ ton/ha dan untuk kelas produksi tinggi yaitu $>8-10$ ton/ha. Dari hasil pengukuran produksi yang telah dilakukan, setiap petak sawah memperoleh hasil yang berbeda. Dari 63 petak sawah yang menjadi data penelitian terdapat 15 petak produksi rendah, 39 petak produksi sedang dan terdapat 9 petak produksi tinggi. 63 petak sawah yang telah diketahui nilai produksinya kemudian dijadikan training area untuk klasifikasi citra pada software.

hasil akhir dari klasifikasi. Pengumpulan seluruh hasil klasifikasi untuk menentukan hasil akhir disebut aggregation.

\section{Persentase Tingkat Produksi Lahan Sawah}

Berdasarkan hasil perhitungan tingkat produksi lahan sawah akan diklasifikasi dengan kelas berbeda maka diperoleh persentase untuk setiap kelas sebagai berikut:

Tabel 3. Hasil Identifikasi Tingkat Produksi Lahan Sawah

\begin{tabular}{|c|c|c|c|}
\hline No & $\begin{array}{l}\text { Tingkat } \\
\text { Produksi }\end{array}$ & Jumlah Petak & Persentase \\
\hline 1 & Rendah & 15 & $24 \%$ \\
\hline 2 & Sedang & 39 & $62 \%$ \\
\hline 3 & Tinggi & 9 & $14 \%$ \\
\hline \multicolumn{2}{|c|}{ Total } & 63 & $100 \%$ \\
\hline
\end{tabular}

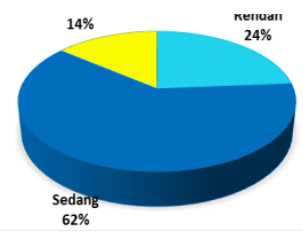

Gambar 6. Diagram Persentase Tingkat Produksi Lahan Sawah

Dari data tersebut diketahui bahwa persentase tertinggi dihasilkan oleh kelas sedang. Jika dilihat dari 
tingkat produksi lahan sawah, terdapat 39 petak produksi sedang, dibangingkan dengan produksi rendah 15 petak dan tinggi 9 petak. Maka, hasil persentase kelas sedang merupakan persentase yang paling tinggi dibandingkan dengan kelas rendah dan kelas tinggi. Selain itu, di lokasi penelitian pada lahan yang luas pemupukannya tidak merata, dan mempengaruhi pada tingkat produksi lahan sawah.

\section{Klasifikasi Tingkat Produksi Lahan Sawah}

1. Peta Klasifikasi Tingkat Produksi Lahan Sawah

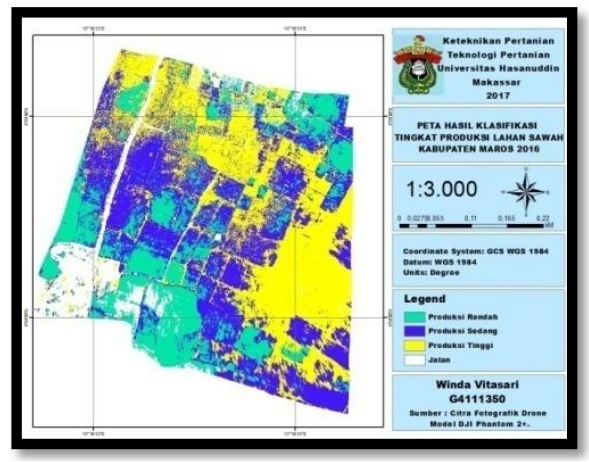

Gambar 7. Peta Klasifikasi Tingkat

Produksi Lahan Sawah Desa Alatengngae

Pada penelitian ini, menggunakan klasifikasi terpantau (supervised classification) dengan metode maximum likehood standard (peluang maksimum) yang dilakukan pada software Arcgis 10.1. Sebelum diolah kedalam software pengolah data citra dilakukan tarining area pada petak yang dijadikan penelitian. Training area dilakukan dengan mengambil beberapa petak sawah yang telah diketahui hasilnya dari data lapangan yang selanjutnya digunakan untuk memisahkan tingkatan suatu lahan sawah. Berdasarkan kelas yang telah ditentukan oleh peneliti yaitu untuk klasifikasi rendah memiliki produksi kisaran 2-5 ton/ha, untuk sedang dengan kisaran produksi $>5$ 8 ton/ha, sedangkan produksi tinggi antara >8-10 ton/ha.

Setelah dilakukan klasifikasi terpantau (supervised classification) untuk kelas rendah, sedang dan tinggi, diketahui peta hasil klasifikasi menunjukkan bahwa tidak semua kelas yang terklasifikasi menghasilkan jumlah yang sama sebelum dan sesudah proses klasifikasi. Untuk produksi rendah dari jumlah 15 petak dihasilkan 14 petak, produksi sedang dari jumlah 39 menghasilkan 32 petak, sedangkan produksi tinggi dari jumlah 9 menghasilkan 17 petak. Hal ini menunjukkan pada proses klasifikasi terdapat kesalahan identifikasi kelas tinggi, sedang dan rendah. Dalam klasifikasi warna dari tiap petak sawah berpengaruh pada proses klasifikasi dan pada saat melakukan training area dilakukan dengan teliti agar tidak terjadi kesalahan dalam tahap klasifikasi

\section{Hasil Data Klasifikasi Lahan Sawah}

Berdasarkan hasil klasifikasi tingkat produksi lahan sawah diperoleh persentase pada tabel di bawah ini :

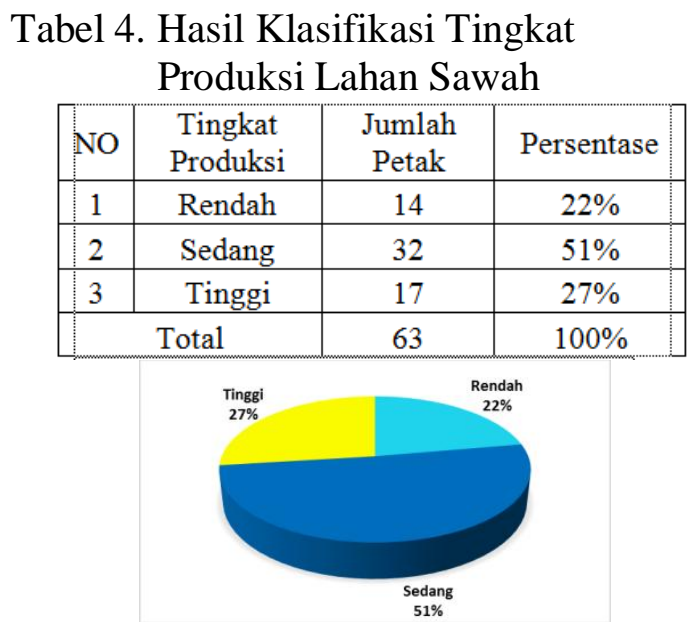

Gambar 8. Diagram Hasil Klasifikasi Luas Lahan Sawah Berdasarkan Tingkat Produksi Lahan Sawah

Dibandingkan dengan data lapangan yang telah diperoleh, persentase produksi sedang mengalami penurunan dari $62 \%$ menjadi $51 \%$ begitupun pada persentase produksi rendah turun dari $24 \%$ menjadi $22 \%$. Namun pada pesentase produksi tinggi mengalami kenaikan dari $14 \%$ menjadi $27 \%$. Hal ini membuktikan bahwa, pada saat klasifikasi terdapat beberapa petak yang teridentifikasi salah dari kenyataan di lapangan, dan 
berpengaruh pada hasil persentase yang akan dihasilkan.

\section{Hasil Validasi Data}

Berdasarkan data hasil pengukuran lapangan pada lahan sawah serta hasil produksi setelah klasifiksi, diperoleh nilai sebagai berikut

Tabel 5. Validasi Data Produktivitas Lahan Sawah

\begin{tabular}{|c|c|c|c|c|c|}
\hline Fakta & Rendah & Sedang & Tinggi & Jumlah & $\begin{array}{c}\text { Producer } \\
\text { Accuracy (\%) }\end{array}$ \\
\hline Rendah & 10 & 5 & 0 & 15 & 66,66 \\
\hline Sedang & 4 & 27 & 8 & 39 & 69,23 \\
\hline Tinggi & 0 & 0 & 9 & 9 & 100 \\
\hline Jumlah & 14 & 32 & 17 & 63 & - \\
\hline $\begin{array}{c}\text { User } \\
\text { Accurary } \\
(\%)\end{array}$ & $71,42 \%$ & $84,37 \%$ & $53 \%$ & - & - \\
\hline
\end{tabular}

\section{Analisis Tingkat Akurasi Citra} Fotografik

Tabel 6. Persentase Tingkat Akurasi

\begin{tabular}{|c|c|c|c|c|c|}
\hline $\begin{array}{l}\text { Tingkat } \\
\text { Produksi }\end{array}$ & $\begin{array}{c}\text { Producer } \\
\text { Accuracy } \\
(\%)\end{array}$ & $\begin{array}{l}\text { Ommision } \\
\text { Error (\%) }\end{array}$ & $\begin{array}{c}\text { User } \\
\text { Accurary } \\
(\%)\end{array}$ & $\begin{array}{c}\text { Commision } \\
\text { Error (\%) }\end{array}$ & $\begin{array}{c}\text { Overall } \\
\text { Accuracy } \\
(\%)\end{array}$ \\
\hline Rendah & 66,66 & 33,33 & 71,42 & 28,57 & \multirow{3}{*}{73,01} \\
\hline Sedang & 69,23 & 30,76 & 84,37 & 15,6 & \\
\hline Tinggi & 100 & 0 & $53 \%$ & 47,05 & \\
\hline
\end{tabular}

Dari hasil validasi data diperoleh persentasi produser accuracy (untuk mengetahui tingkat akurasi berdasarkan fakta yang diperoleh di lapangan), dan user accuracy (sesuai dengan keinginan penelitian ketika dalam kelas sedang dan tinggi masih melenceng dari kelas yang telah di tetapkan sebelumnya), ommision error (untuk mengetahui kesalahan yang terjadi pada pembacaan citra dengan melihat kenyataaan di lapangan), commission error (untuk mengetahui kesalahan yang terjadi pada proses identifikasi citra yang dilakukan pada perangkat lunak data raster dan vektor). Validasi data digunakan untik mengetahui tingakat ketelitian hasil klasifikasi citra dengan data.

Berdasarkan Tabel 7, dapat diketahui kesalahan (error) yang paling sering terjadi dalam penelitian ini adalah mengkategorikan sedang menjadi tingkat produksi tinggi. Karena memiliki kemiripan bentuk fisik akan memancarkan panjang gelombang yang sama atau hampir sama. Dapat dilihat tingkat akurasi tiap tingkat produksi bervariasi. Tingkat akurasi keseluruhan pada proses klasifikasi dapat dilihat pada hasil persentase overall accuracy yang mencapai 73,01 \%. Hal ini menandakan bahwa klasifikasi tingkat produski lahan sawah menggunakan citra fotografik dapat diterima, hal ini sesuai dendan pendapat Gallego (1995) bahwa, tingkat ketelitian analisis citra untuk deteksi areal lahan pertanian diatas $70 \%$ dianggap sudah baik

\section{Perhitungan Indeks Vegetasi Tanaman Padi}

a. Normalized Difference Vegetation Index (NDVI)

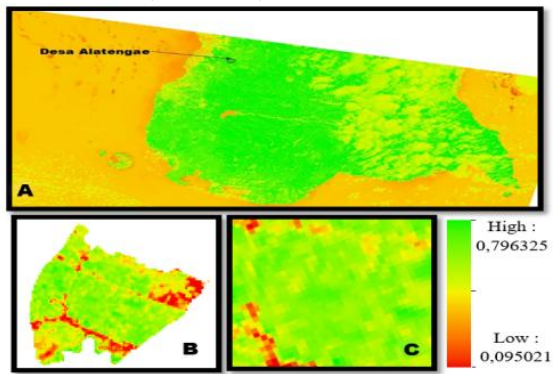

Gambar 9. Citra landsat untukIndeks Vegetasi NDVI (a) Desa Alatengae Kecamatan Bantimurung, (b) Desa Alatengae setelah dipotong, (c) Lokasi Penelitian

\section{b. Green Normalized Difference} Vegetation Index (GNDVI)

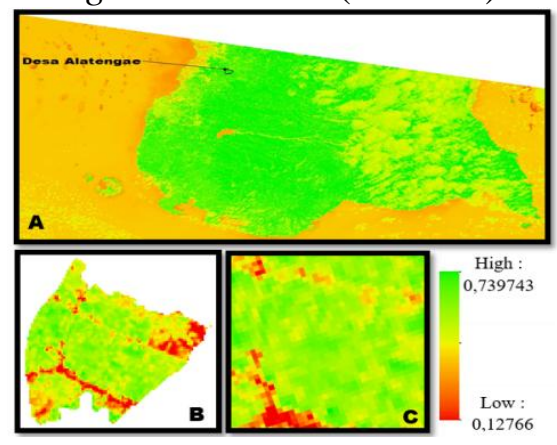

Gambar 10. Citra Landsat 8 untuk Indeks Vegetasi GNDVI (a) Desa Alatengae Kecamatan Bantimurung, (b) Desa Alatengae setelah dipotong, (c) Lokasi Penelitian 
c. Visible Atmospherically Resistant Index (VARIgreen)

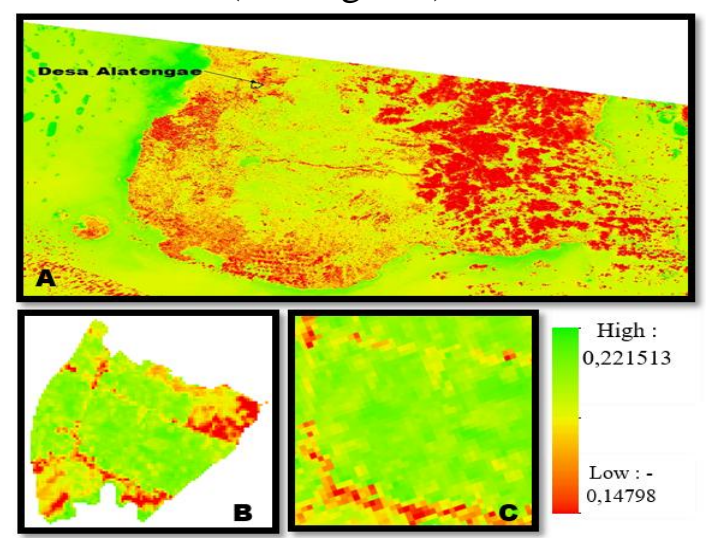

Gambar 11. Citra Landsat 8 untuk Indeks Vegetasi VARIgreen (a) Desa Alatengae

Kecamatan Bantimurung, (b) Desa Alatengae setelah dipotong, (c) Lokasi Penelitian

Dari ketiga citra yang dihasilkan memiliki perbedaan warna dan nilai yang dihasilkan, ketigan indeks yang digunakan merupakan indeks pendektesi kehijauan pada lokasi penelitian. Indeks vegetasi kehijauan terdeteksi pada nilai rentan 0,20,8 . Hal ini sesuai dengan pendapat Munajat Nursaputra (2014) menyatakan, pada umunya vegetasi yang hijau terdeteksi pada nilai rentan antara 0,2 0,8 . Nilai indeks ini dapat diklasifikasikan untuk menentukan tingkat kerapatan tutupan lahan, tingkat kehijauan suatu tanaman tingkat kesehatan tanaman.

Pada Gambar 9. Yaitu citra Landsat 8 untuk indeks NDVI menunjukkan tingkat kehijauan yang rendah karena hanya memiliki nilai vegetasi paling rendah 0,095021 dan paling tinggi 0,796325. Begitu pula dengan kedua Citra lainnya pada Gambar 10. Untuk nilai indeks vegetasi GDNVI menunjukkan tingkat kehijauan yang rendah, hanya memiliki nilai vegetasi paling rendah 0,12766 dan paling tinggi 0,739743 . Nilai indeks vegetasi pada Gambar 11. Menunjukkan tingkat kehijauan rendah 0,14798 dan paling tinggi 0,221513 .

\section{Indeks Vegetasi Penentuan Tingkat Kehijauan Padi}

Nilai indeks tersebut tentunya mempengaruhi tingkat kehijauan yang terdapat di lokasi penelitian.

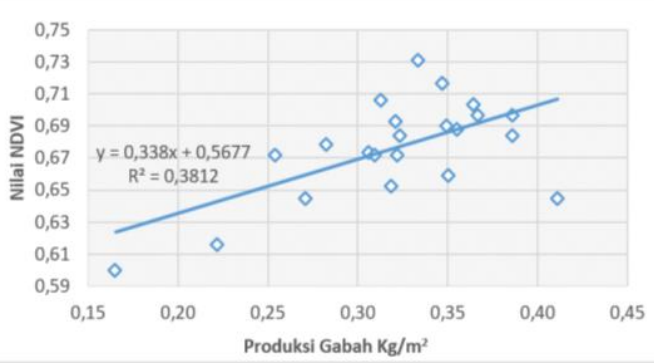

Gambar 12. Grafik Hubungan Indeks Vegetasi NDVI dan Produksi Tanaman

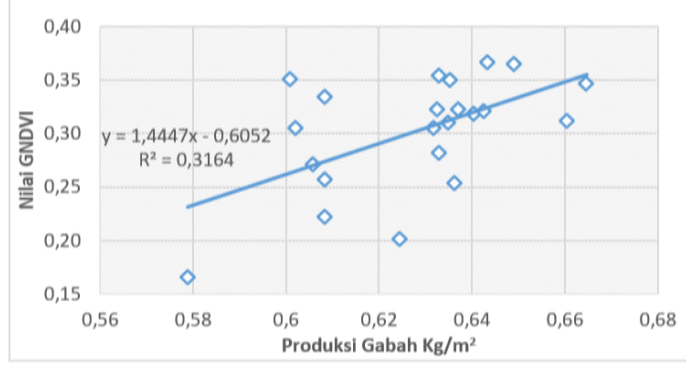

Gambar 13. Grafik Hubungan Indeks Vegetasi GNDVI dan Produksi Tanaman

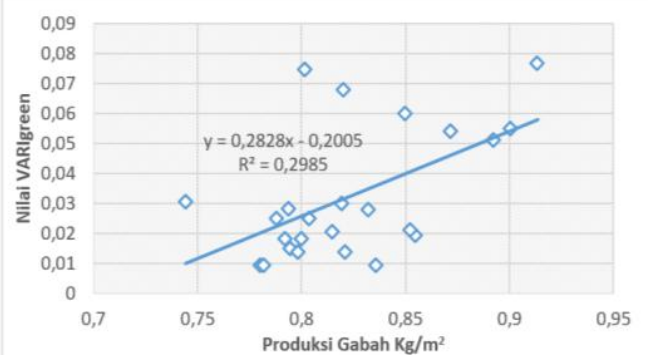

Gambar 14. Grafik Hubungan Indeks Vegetasi VARIgreen pada Citra Landsat 8 dan Citra Fotografik UAV

Gambar di atas menunjukkan masing-masing R2 atau koefisien determenasi yang diperoleh dari ke tiga indeks vegetasi yang digunakan, terdapat 22 petak sawah yang dijadikan sampel untuk dilihat seberapa besar tingkat kehijauan yang diperoleh lahan tersebut. Setelah itu di bandingkan produksi gabah yang di hasilkan pada petak yang dijadikan sampel.

Pada Gambar 12. yaitu hubungan indeks vegetasi NDVI di lokasi penelitian menghasilkan nilai $\mathrm{R} 2=0,3812$, yang menunjukkan bahwa nilai kehijauannya 
rendah. Begitu pulan pada Gambar 13 . Untuk indeks vegetasi GNDVI yang memiliki nilai $\mathrm{R} 2=0.3164$. Keduanya menunjukkan tingkat vegetasi rendah. Sedangkan Gambar 14. Untuk indeks vegetasi VARIgreen pada citra Landsat 8 dan citra fotografik UAV menghasilkan nilai $\mathrm{R} 2=0,2985$.

Menurut Kusumawardani (2013), tanaman padi memiliki karakteristik yang khas. Pada awal pertumbuhan tanaman padi areal sawah selalu digenangi dan kenampakan yang dominan adalah kenapampakan air (fase air). Seiring dengan pertumbuhannya, kondisi lahan sawah akan berubah didominasi oleh daundaun padi (vase vegetatif). Pada saat puncak pertumbuahan vegetatif terjadi tingkat kehijaun yang tinggi disebabkan oleh tingginya kandungan klorofil. Setelah masa tersebut, tingkat kehijauan akan menurun, timbul bunga-bunga padi sampai menguning (fase generatif).

Nilai R2 yang dihasilkan dari ketiga indeks vegetasi yang digunakan peneliti tentu berpengaruh pada proses atau fase pertumbuhan padi sawah tersebut. Citra landsat 8 yang gunakan peneliti yaitu pada tanggal 24 Agustus 2016, pada saat itu tanaman padi berumur 95 HST (hari setelah taman). Pada HST tersebut sudah mulai tumbuh bulir padi dan warna padi mulai berubah menjadi kuning. Menurut widjojo (2013), padi yang berumur 75-90 atau 90-105 menandakan tanaman padi mendekati masa panen. Hal tersebut berpengaruh pada vegetasi tanaman padi tersebut. Ini sesuai dengan pendapat Wahyunto (2006) menyatakan nilai indeks semakin tinggi seiring dengan bertambahnya umur, kemudian mencapai maksimum pada umur tertentu yaitu pada saat bunting (pinnacle initiation). Selanjutnya nilai indeks vegetasinya semakin menurun selama fase pengisian-pematangan bulir hingga menjelang panen.

\section{Indeks Vegetasi Berdasarkan Varietas Padi}

Varietas merupakan salah satu komponen teknologi penting yang mempunyai kontribusi besar dalam mengingkatkan produksi dan pendapatan usahatani. Varietas padi merupakan sekelompok tanaman dari suatu jenis atau spesies tanaman yang memiliki karakteristik ertentu seperti bentuk, pertumbuhan tanaman, daun, bunga dan biji yang dapat membedakan dari jenis atau spesies tanaman lain, dan apabila diperbanyak tidak mengalami perubahan.

Pada lokasi penelitian, terdapat beragam varietas padi. Terdapat enam varietas padi yang ditanam petani Desa Alatengae. Akan tetapi peneliti hanya mengambil tiga varietas sebagai data penelitian yaitu varietas inpari 4 , inpari 23 dan ciliwung. Dari ke tiga varietas tersebut masing-masing dilihat indeks vegetasinya. Dan dari nilai indeks vegetasi, diketahui bahwa indeks vegetasi yang paling tinggi nilainya merupakan nilai yang cocok di gunakan untuk menlihat indeks vegetasi pada varietas tertentu.

Total petak yang diteliti yaitu sembilan petak, dengan tiga varietas inpari 4, tiga varietas inpari 23 dan tiga petas varietas ciliwung. Varietas inpari 4 terdapat pada petak 56, 153 dan 155. Sedang varietas inpari 23 terdapat pada petak 78, 89 dan 151. Varietas ciliwung terdapat pada petak 67, 128, dan 205. Terdapat perbedaan nilai indeks vegetasi pada setiap petak tersebut. Perbedaan tersebut dipengaruhi dari tingkat kehijauan masing-masing petak dan kondisi padi tersebut. 


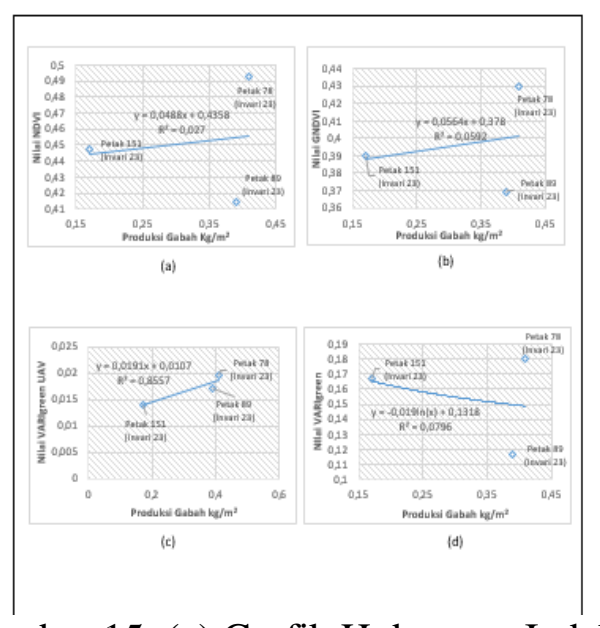

Gambar 15. (a) Grafik Hubungan Indeks Vegetasi NDVI dan Produksi Tanaman pada Varietas Inpari 23. (b) Grafik

Hubungan Indeks Vegetasi GNDVI dan Produksi Gabah pada Varietas Inpari 23.

(c) Grafik Hubungan Indeks Vegetasi

VARUgreen UAV dan Produksi Gabah pada Varietas Inpari 23. (d) Grafik

Hubungan Indeks Vegetasi VARIgreen

Landsat 8 dan Produksi Gabah Varietas Inpari 23.

Grafik perbandingan indeks vegetasi di atas menunjukkan bahwa nilai indeks vegetasi VARIgreen UAV Gambar (c) merupakan nilai tertinggi dari ketiga indeks vegetasi lainnya. Nilai yang diperoleh yaitu $\mathrm{R} 2=0,8557$, dari nilai tersebut diketahui indeks ini baik digunakan untuk padi varietas 23 . Karena dari ketiga indeks tersebut dapat mendekteksi nilai kehijauan yang tinggi.

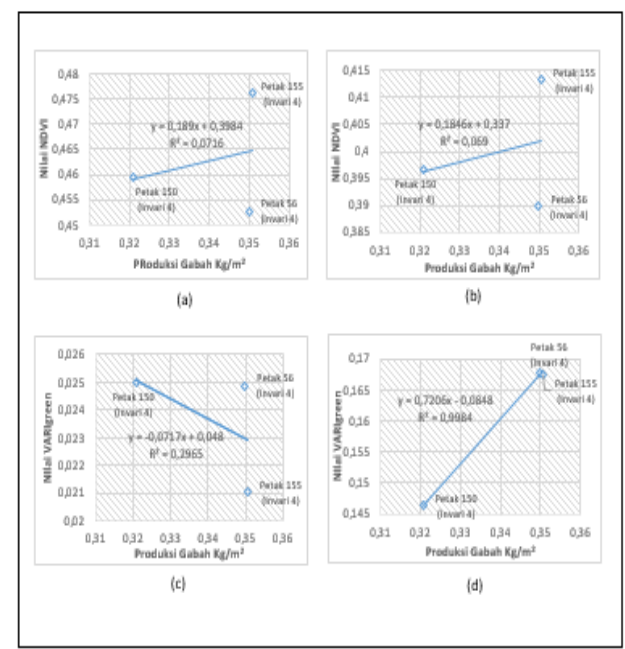

Gambar 16. (a) Grafik Hubungan Indeks Vegetasi NDVI dan Produksi Gabah Pada
Varietas Inpari 4. (b) Grafik Hubungan Indeks Vegetasi GNDVI dan Produksi Gabah Pada Varietas Inpari 4. (c) Grafik Hubungan Indeks Vegetasi VARIgreen UAV dan Produksi Gabah pada Varietas Inpari 4. (d) Grafik Hubungan Indeks Vegetasi VARIgreen Landsat 8 dan

Produksi Gabah pada Varietas Inpari 4.

Indeks vegetasi untuk padi varietas ciliwung memiliki nilai yang cukup tinggi dibandingkan dengan varietas inpari 4 dan inpari 23. Pada gambar 22 yaitu hubungan indeks vegetasi menggunakan VARIgreen citra Landsat 8 diperoleh nilai $\mathrm{R} 2=1$. Nilai tersebut merupakan nilai tertinggi, dan indeks tersebut dapat digunakan untuk mengetahui tingkat kehijauan padi pada varietas ciliwung.

\section{KESIMPULAN DAN SARAN}

\section{Kesimpulan}

Dari hasil evaluasi klasifikasi dan data lapangan di peroleh kesimpulan sebagai berikut :

1. Hasil klasifikasi terpantau menunjukkan persentase luasan area untuk produksi rendah $22 \%$, produksi sedang $51 \%$ dan tinggi $27 \%$.

2. Hasil klasifikasi citra VAU menunjukkan produksi petakan sawah dengan overall accuracy 73,01\%.

3. Indeks vegetasi yang terbaik dalam pendugaan produksi pada tingkat varietas adalah indeks vegetasi VARIgreen.

Saran

Penelitian ini dapat dilakukan dengan pendekatan lain seperti analisis ANN (Arctifical Neural Network) dan lainnya.

\section{DAFTAR PUSTAKA}

Abdurrachman, Irfan M. 2013. Kajian Potensi Bionutrien Caf dengan Penambahan Ion Logam Terhadap Pertumbuhan dan Perkembangan 
Tanaman Padi. Universitas Pendidikan Indonesia:

Aini, Anisah. 2015. Sistem Informasi Geografis Pengertian dan Aplikasinya. STIMIK A MIKOM: Yogyakarta.

Azwir \& Ridwan. 2009. Peningkatan Produktivitas Padi Sawah dengan Perbaikan Teknologi Budidaya. Akta Agrosia, Vol. 12, No. 2 hlm 212-218 Juli-Des.

Cifor. (2014). Penginderaan Jauh Online: http://www.cifor.org. Retrieved. Agustus 28. 2014.

Dwi, Anang P., Wikanti A., dan Gathot W. 2014. Analisis Sebaran dan Kerapatan Mangrove Menggunakan Citra Landsat $8 d u$ Segara Anakan, Cilacap. Pusat Pemanfaatan Penginderaan Jauh: LAPAN.

Faizal, Ahmad \& Anshar, Muhammad Amran. 2005. Model Transformasi Indeks Vegetasi Yang Efektif Untuk Prediksi Kerapatan Mangrove Rhizophora Mucronata. Institut Teknologi Sepuluh Nopember; Surabaya.

Frananda, Hendry., Hartono., dan Heru Retnadi Jatmiko. Komparasi Indeks Untuk Estimasi Stok Karbon Hutan Mangrove Kawasan Segoro Anak Pada Kawasan Taman Nasional Asal Purwo Banyuwangi, Jawa Timur. Majalah Ilmiah Globe Volume 17 No. 2 Desember 2015:113-123.

G.E Bell., B.M. Howell., dan G.v. Johnson. Optical Sensing of Turgrass Chorophyll Content and Tissue Nitrogen. Hort Science 39(5):1130-1132. 2004.

I Made Parsa. Kajian Pendekatan Teori Probabilitas untuk Pemetaan Lahan Sawah Berbasis Perubahan Penutup Lahan Citra Landsat Multiwaktu (Studi Kasus Daerah Tanggamus, Lampung). Jurnal Penginderaan Jauh. Vol. 10, No. 2 Desember 2013:113-121.
Kresna, Erie A. 2015. Pengembangan Data Citra Satelit Landsat-8 untuk Pemetaan Area Tanaman Hortikultura dengan Berbagai Metode Algoritma Indeks Vegetasi (Studi Kasus: Kabupaten Malang dan Sekitarnya). Institiut Teknologi Sepuluh Nopember: Surabaya.

Kusumawardani, Ratih., Widjojo S., dan Irmadi N. Inventarisasi Produksi Padi Dengan Menggunakan Data Citra Modis di Kabupaten Lebak, Provinsi Banten. Jurnal Globe Volume 15 No. 1 Juni 2013:12-22.

Loppies, R. 2010. Karakteristik dan Spesifikasi Satelit Landsat. Inderaja: Bandung.

Mustika, Nurwita S., \& Dony K. Klasifikasi Penutup Lahan Berbasis Obyek pada Data Foto untuk Mendukung Penyediaan Informasi Penginderaan Jauh Skala Rinci. Jurnal Penginderaan Jauh. Vol. 11 No. 2, Desember 2014:114-127.

Nursaputra, Munajat. 2014. Deteksi Tingkat Kesehatan Hutan Sebagai Upaya Perlindungan dan Pelestarian Ekosistem Penting Dalam Pengolaan Daerah Aliran Sungai. Universitas Gadjah Mada; Yogyakarta.

Peasetyo, Dodik, Prabowo,. Bachri Syamsul., dan Setiabudi B.W. Prediksi Perubahan Penggunaan Lahan dan Pola Berdasarkan Citra Landsat Multiwaktu Dengan Land Change Modeler (LCM) Idrisi Selva 17: Studi Kasus Sub-Das Brantas Hulu. Jurnal Pendidikan Geografi Tahun 22, No. 1 Januari 2017 Hal: 32-48.

Rahayu \& Danang S.C. 2014. Koreksi Radiometrik Citra Landsat-8 Kanal Multispektral Menggunakan Top of Atmosphere (TOA) untuk Mendukung Klasifikasi Penutupan Lahan. Pusat Teknologi dan Data Penginderaan Jauh. LAPAN. 
Ramadhani, Yoniar H., Rokhmatulloh, Aris P., dan Susanti R. Pemetaan Pulau Kecil dengan Pendekatan Berbasis Objek Menggunakan Data Unmanned Arial Vehicle $(U A V)$. Majalah Ilmiah Globe. Vol. 17, No. 2 Desember 2015:125-134.

Santi, R. C. (2011). Teknik Perbaikan Kualitas Citra Satelit Cuaca Dengan Sataid. Jurnal Teknologi Informasi DINAMIK Volume 16, 101-109.

Shofiyanti, Rizatus. 2011. Teknologi Pesawat Tanpa Awak untuk Pemetaan dan Pemantauan Tanaman dan Lahan Pertanian. Informatika Pertanian, Vol. 20, No. 2, p: 58-64.

Sukojo, B. M., \& Kustarto, H. (2002). Perbaikan Geometrik Trase Jaringan Jalan dengan Menggunakan Teknologi Penginderaan Jauh dan Sistem Informasi Geografis. Makara Sains, 136-141.

Suryo, Nanik H., Sayidah S., Junita M.P., dan Hana L.F. Klasifikasi Daerah Tercemar Limbah Acid Sludge Menggunakan Metode Spectral Maxture Analisis Berbasis Data Landsat 8. Jurnal Penginderaan Jauh. Vol. 12, No. 1 Juni 2015:13-28.

Susetyo, Imam \& Setiono. 2013. Aplikasi Penginderaan Jauh Untuk Mendukung Sistem Manajemen Lahan Perkebunan Yang Berkelanjutan di Perkebunan Karet. Balai Penelitian Gates, Jl, Patimura Km 6, Kotak Pos 804 Salatiga 20702. Warta Perkaretan, 32(2), 205-113.

Via, Mei Savitri., Sudarwati Henri., dan Hermanto. 2012. Pengaruh Umur Pemotongan Terhadap Produktivitas Gamal (Glir-icidia sepium). Jurnal Ilmu-Ilmu Peternakan 23 (2): 25-35.

Widago, Wahyunto \& Bambang H. 2006. Pendugaan Produktivitas Tanaman
Padi Sawah Melalui Analisis Citra Satelit. Informatika Pertanian Vol. 15. 